\title{
Inhibitory Mechanism of Carbon Steel Corrosion in Sea Water by an Aqueous Extract of Henna Leaves
}

\author{
V. Johnsirani, ${ }^{1}$ J. Sathiyabama, ${ }^{1}$ Susai Rajendran, ${ }^{1,2}$ and A. Suriya Prabha ${ }^{3}$ \\ ${ }^{1}$ PG and Research Department of Chemistry, GTN Arts College, Tamil Nadu, Dindigul 624005, India \\ ${ }^{2}$ Department of Chemistry, RVS School of Engineering and Technology, Dindigul 624005, India
}

${ }^{3}$ Department of Chemistry, Shanmuganathan Engineering College, Arasampatti 622507, India

Correspondence should be addressed to V. Johnsirani, johnsirani15@gmail.com

Received 19 September 2012; Accepted 27 October 2012

Academic Editors: A. A. Franco and E. Stupnisek-Lisac

Copyright (C) 2012 V. Johnsirani et al. This is an open access article distributed under the Creative Commons Attribution License, which permits unrestricted use, distribution, and reproduction in any medium, provided the original work is properly cited.

\begin{abstract}
The inhibition efficiency (IE) of an aqueous extract of henna leaves in controlling corrosion of carbon steel in seawater has been evaluated by weight-loss method. The weight loss study reveals that the formulation consisting of $8 \mathrm{~mL}$ of henna extract (HE) and $25 \mathrm{ppm}$ of $\mathrm{Zn}^{2+}$ has $94 \%$ inhibition efficiency in controlling corrosion of carbon steel in sea water. Polarization study reveals that $\mathrm{HE}$ and $\mathrm{Zn}^{2+}$ system functions as mixed type inhibitor. AC impedance spectra reveal that protective film is formed on the metal surface. The nature of the metal surface has been analysed by FTIR spectra, SEM, and AFM analysis.
\end{abstract}

\section{Introduction}

Sea water is one of the most corroded and most abundant naturally occurring electrolytes. The corrosive behaviour of seawater is reflected by the fact that most of the common structural metals and alloys are attacked by this liquid or its surrounding environments. The sea water environments can be divided into five zones, namely, subsoil, continuously submerged, tidal, splash zone above high tidal, and atmospheric zone [1]. The corrosion behaviour of metals and alloys differs from one zone to another. In splash zone the stainless steels have usually satisfactory performance while the carbon and low alloy steels do not. Anderson and Ross had found that the austenitic grades performed much better than martensitic and ferritic grades [2]. The $\mathrm{Ni}, \mathrm{Cu}$, and $\mathrm{P}$ alloyed steels were found to be much more resistant than carbon steel in splash zone [3]. Also, it was found that Mn, $\mathrm{P}$, and $\mathrm{Al}$ had measurable influence on corrosion rates of low carbon steels under tidal exposure. After 5-year exposure test, it was found that the rate of attack in splash zone was much higher than the atmospheric $\pi$ and deep submerged zones [4].

Metals and alloys are often exposed to the action of acids and alkalis in industrial processes thereby prompting their deterioration [5]. One of the most effective means of protecting metals and alloys surfaces from corrosion in acid and alkaline environments is the use of corrosion inhibitors [6]. Corrosion inhibitors are usually added to the acid/alkaline solution to reduce the metal loss. Recently, studies on the use of drugs have been reported by several researchers [7, 8]. Some of these corrosion inhibitors are, however, toxic to the environment. This has prompted the search for green corrosion inhibitors that are nontoxic and ecofriendly for metals and alloys in acidic and alkaline solutions [9]. These green corrosion inhibitors have been found to have centre for $\pi$-electrons and functional groups (such as $-\mathrm{C}=\mathrm{C}-,-\mathrm{OR}$, $-\mathrm{OH},-\mathrm{NR}_{2},-\mathrm{NH}_{2}$, and $-\mathrm{SR}$ ) which provide electrons that facilitate the adsorption of the inhibitor on the metal/alloy surface.

Before the 1960s, inorganic inhibitors such as zinc, chromate, polyphosphate, and nitrites were used as inhibitors. However, discharge of such material has become unacceptable due to environmental hazards [10]. The recent trend is towards environmental friendly inhibitors. Increasing awareness of health and ecological risk has drawn attention to finding more suitable inhibitors, which are nontoxic. Accordingly, greater research efforts have been directed towards formulating environmentally acceptable inhibitors. 
The extracts from plant leaves, roots, and seeds have been studied and found to be cheap, environmental friendly, and good corrosion inhibitors. The plant leave extracts studied include Opuntia extract [11], Carica papaya (CP) and Azadirachta indica (AI) [12], Vernonia amygdalina [13], Telfairia occidentalis [14], Phyllanthus amarus [15], fenugreek leaves [16], olive leaves [17], Euphorbia hirta, and Dialium guineense [18]. The roots studied include ginseng root [19], Beet root extract [20], Kopsia singaporensis extract [21], and Murraya koenighii [22]. The present work is undertaken.

(1) To evaluate the inhibition efficiency (IE) of henna extract (HE) $-\mathrm{Zn}^{2+}$ system in controlling corrosion of carbon steel immersed in sea water in the absence and presence of $\mathrm{Zn}^{2+}$ by weight-loss method.

(2) To study the mechanism of corrosion inhibition by polarization study and AC impedance spectra.

(3) To analyse the protective film by FTIR spectra, scanning electron microscope (SEM), and atomic force microscope.

(4) To propose the mechanism of corrosion inhibition based on the above results.

\section{Experimental}

2.1. Preparation of Plant Extract. The leaves of henna were dried and ground to powder and $10 \mathrm{gm}$ of the powdered leaves weighed and boiled with double-distilled water, filtering the suspending impurities and making up to $100 \mathrm{~mL}$. The extract was used as corrosion inhibitor in the present study.

2.2. Preparation of the Specimens. Carbon steel specimens (0.026\% S, $0.06 \% \mathrm{P}, 0.4 \% \mathrm{Mn}, 0.1 \% \mathrm{C}$ and rest iron) of the dimensions $1.0 \times 4.0 \times 0.2 \mathrm{~cm}$ were polished to a mirror finish, degreased with trichloroethylene, and used for the weight-loss method and surface examination studies.

\subsection{Weight-Loss Method}

2.3.1. Determination of Surface Area of the Specimens. The length, breadth, and the thickness of carbon steel specimens and the radius of the holes were determined with the help of vernier calipers of high precision, and the surface areas of the specimens were calculated.

2.3.2. Weighing the Specimens before and after Corrosion. All the weighing of the carbon steel specimens before and after corrosion was carried out using Shimadzu Balance-AY62.

2.3.3. Determination of Corrosion Rate. The weighed specimens in triplicate were suspended by means of glass hooks in $100 \mathrm{~mL}$ beakers containing $100 \mathrm{~mL}$ various test solutions, and after 24 hours of immersion, the specimens were taken out, washed in running water, dried, and weighed. From the change in weights of the specimens, corrosion rates were calculated using the following relationship:

$$
\text { Corrosion rate }(\mathrm{mm} / \text { year })=87.6 \mathrm{~W} / \mathrm{DAT} \text {, }
$$

where $W=$ weight-loss in milligrams, $D=$ density of specimen $\mathrm{g} / \mathrm{cm}^{3}, A=$ area of specimen in square $\mathrm{cm}$, and $T=$ exposure time in hours.

Corrosion inhibition efficiency (IE) was then calculated using the equation

$$
\mathrm{IE}=100\left[1-\left(\frac{W_{2}}{W_{1}}\right)\right] \%,
$$

where $W_{1}=$ corrosion rate in the absence of inhibitor and $W_{2}=$ corrosion rate in the presence of inhibitor.

2.4. Surface Examination Study. The carbon steel specimens were immersed in various test solutions for a period of one day. After one day, the specimens were taken out and dried. The nature of the film formed on the surface of metal specimen was analyzed by various surface analysis techniques.

2.5. Potentiodynamic Polarization. Polarization studies were carried out in a CHI electrochemical workstation with impedance model $660 \mathrm{~A}$. It was provided with IR compensation facility. A three-electrode cell assembly was used. The working electrode was carbon steel. A SCE was the reference electrode. Platinum was the counter electrode. From polarization study, corrosion parameters such as corrosion potential $\left(E_{\text {corr }}\right)$, corrosion current $\left(I_{\text {corr }}\right)$, Tafel slopes anodic $=b_{a}$, and cathodic $=b_{c}$ were calculated, and linear polarization study (LPR) was done. The scan rate $(V / S)$ was 0.01 . Hold time at $\left(E_{\mathrm{fcs}}\right)$ was zero and quiet time $(\mathrm{s})$ was two.

2.6. AC Impedance Spectra. The instrument used for polarization study was used to record AC impedance spectra also. The cell set up was also the same. The real part $\left(Z^{\prime}\right)$ and imaginary part $\left(Z^{\prime \prime}\right)$ of the cell impedance were measured in ohms at various frequencies. Values of charge transfer resistance $\left(R_{t}\right)$ and the double layer capacitance $\left(C_{\mathrm{dl}}\right)$ were calculated.

2.7. Fourier Transform Infrared Spectra. These spectra were recorded in a Perkin-Elmer-1600 spectrophotometer using $\mathrm{KBr}$ pellet. The FTIR spectrum of the protective film was recorded by carefully removing the film, mixing it with $\mathrm{KBr}$ and making the pellet.

2.8. Scanning Electron Microscopic Studies (SEM). The carbon steel immersed in blank solution and in the inhibitor solution for a period of one day was removed, rinsed with double-distilled water, dried, and observed in a scanning electron microscope to examine the surface morphology. The surface morphology measurements of carbon steel were examined using JEOL MODEL6390 computer-controlled scanning electron microscope.

2.9. Atomic Force Microscopy Characterization (AFM). The carbon steel specimens immersed in blank and in the inhibitor solution for a period of one day were removed, 
TABLE 1: Water analysis (Thondi sea water, Tamil Nadu, India).

\begin{tabular}{lc}
\hline Parameters & Result \\
\hline Total dissolved salts $(\mathrm{mg} / \mathrm{L})$ & $30539 \mathrm{ppm}$ \\
Electrical conductivity (micro mhos/cm) & 44910 \\
$\mathrm{pH}$ & 7.06 \\
Total hardness $\left(\mathrm{CaCO}_{3}\right.$ equivalent) & $100 \mathrm{ppm}$ \\
Calcium as $\mathrm{Ca}(\mathrm{mg} / \mathrm{L})$ & $19 \mathrm{ppm}$ \\
Magnesium as $\mathrm{Mg}(\mathrm{mg} / \mathrm{L})$ & $12 \mathrm{ppm}$ \\
Sodium as $\mathrm{Na}(\mathrm{mg} / \mathrm{L})$ & 0 \\
Chloride as $\mathrm{Cl}(\mathrm{mg} / \mathrm{L})$ & $11400 \mathrm{ppm}$ \\
Fluoride as $\mathrm{F}(\mathrm{mg} / \mathrm{L})$ & 0 \\
Free ammonia as NH$(\mathrm{mg} / \mathrm{L})$ & 0 \\
Sulphate as $\mathrm{SO}_{4}(\mathrm{mg} / \mathrm{L})$ & $6708 \mathrm{ppm}$ \\
\hline
\end{tabular}

rinsed with double-distilled water, dried, and subjected to the surface examination. Atomic force microscopy (Veeco dinnova model) was used to observe the samples' surface in tapping mode, using cantilever with linear tips. The scanning area in the images was $5 \mu \mathrm{m} \times 5 \mu \mathrm{m}$, and the scan rate was $0.6 \mathrm{HZ} /$ second.

\section{Results and Discussions}

3.1. Weight-Loss Study. The physicochemical parameters of sea water are given in Table 1.

The calculated inhibition efficiencies (IEs) of henna extract in controlling the corrosion of carbon steel immersed in sea water both in the absence and presence of zinc ion have been tabulated in Table 2. The calculated values indicate the ability of henna extract to be a good corrosion inhibitor. The inhibition efficiency is found to be enhanced in the presence of zinc ion. The formulation consisting of $8 \mathrm{~mL}$ of $\mathrm{HE}$ and $25 \mathrm{ppm}$ of $\mathrm{Zn}^{2+}$ offers $94 \%$ inhibition efficiency. This mixture of inhibitors shows better IE than the individual inhibitors [23].

3.1.1. Synergism Parameter $\left(S_{I}\right)$. Synergism parameters are indications of synergistic effect existing between inhibitors $[24,25] . S_{I}$ value is found to be greater than one indicating the synergistic effect existing between $\mathrm{Zn}^{2+}$ of concentrations $25 \mathrm{ppm}$ and $50 \mathrm{ppm}$ with various concentrations of HE. The results are given in Table 3.

In Table 3 synergism parameters were calculated using the relation

$$
S_{I}=\frac{1-\theta_{1+2}}{1-\theta_{1+2}^{\prime}},
$$

where

$$
\theta_{1+2}=\left(\theta_{1}+\theta_{2}\right)-\left(\theta_{1} \times \theta_{2}\right)
$$

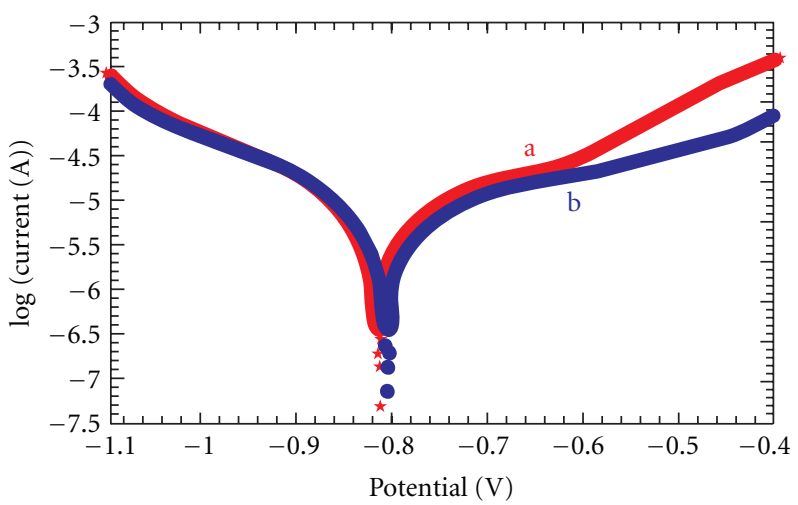

Figure 1: Polarization curves of carbon steel immersed in various test solutions. (a) Sea water and (b) sea water $+\mathrm{HE} 8 \mathrm{~mL}+\mathrm{Zn}^{2+}$ $25 \mathrm{ppm}$.

where $\theta_{1}=$ surface coverage of inhibitor $(\mathrm{HE})$ and $\theta_{2}=$ surface coverage of inhibitor $\left(\mathrm{Zn}^{2+}\right)$ and where

$$
\begin{gathered}
\theta_{1+2}^{\prime}=\text { combined surface coverage of inhibitors } \\
(\mathrm{HE}) \text { and }\left(\mathrm{Zn}^{2+}\right) \\
\text { surface coverage }=\frac{\mathrm{IE} \%}{100} .
\end{gathered}
$$

3.1.2. Analysis of Variance (F-Test). F-test is used to investigate if the synergistic effect existing between two inhibitors is statistically significant or not $[26,27]$. If $F$-value is above 5.32 for 1,8 degrees of freedom, the synergistic effect proves to be statistically significant. If it is below 5.32 for 1,8 degrees of freedom indicating that it is statistically insignificant at a 0.05 level of significance. The results are given in Table 4 .

The obtained $F$-value 0.56 for $25 \mathrm{ppm} \mathrm{Zn}^{2+}$ is not statistically significant, since it is less than the critical $F$-value 5.32 for 1,8 degrees of freedom at 0.05 level of significance. Therefore it is concluded that the influence of $25 \mathrm{ppm} \mathrm{Zn}^{2+}$ on the inhibition efficiencies of various concentrations of $\mathrm{HE}$ is not statistically significant. The obtained $F$-value 3.82 for $50 \mathrm{ppm} \mathrm{Zn}^{2+}$ is not statistically significant, since it is less than the critical $F$-value 5.32 for 1,8 degrees of freedom at 0.05 level of significance. Therefore it is concluded that the influence of $50 \mathrm{ppm} \mathrm{Zn}^{2+}$ on the inhibition efficiencies of various concentrations of $\mathrm{HE}$ is not statistically significant.

3.2. Analysis of Polarization Curves. Polarization study has been used to detect the formation of protective film on the metal surface. When a protective film is formed on the metal surface, the linear polarization resistance (LPR) increases and the corrosion current $\left(I_{\text {corr }}\right)$ decreases. The potentiodynamic polarization curves of carbon steel immersed in various test solutions are shown in Figure 1. The corrosion parameters, namely, corrosion potential ( $\left.E_{\text {corr }}\right)$, Tafel slopes $\left(b_{c}=\right.$ cathodic; $b_{a}=$ anodic $)$, linear polarization resistance (LPR), and corrosion current $\left(I_{\text {corr }}\right)$ are given in Table 5. When carbon steel is immersed in sea water, the corrosion potential is $-816 \mathrm{mV}$ versus SCE. The formulation consisting 
TABLE 2: The corrosion inhibition efficiencies and the corresponding corrosion rates (millimeter per year) of HE- $\mathrm{Zn}^{2+}$ system.

\begin{tabular}{|c|c|c|c|c|c|c|}
\hline \multirow{3}{*}{ Inhibitor HE (mL) } & \multicolumn{6}{|c|}{$\mathrm{Zn}^{2+}(\mathrm{ppm})$} \\
\hline & \multicolumn{2}{|c|}{0} & \multicolumn{2}{|c|}{25} & \multicolumn{2}{|c|}{50} \\
\hline & $\mathrm{IE} \%$ & $\mathrm{CR}(\mathrm{mn} / \mathrm{y})$ & $\mathrm{IE} \%$ & $\mathrm{CR}(\mathrm{mm} / \mathrm{y})$ & $\mathrm{IE} \%$ & $\mathrm{CR}(\mathrm{mm} / \mathrm{y})$ \\
\hline 0 & - & 0.1576 & 16 & 0.1323 & 47 & 0.0835 \\
\hline 2 & 28 & 0.1134 & 41 & 0.0929 & 64 & 0.0567 \\
\hline 4 & 35 & 0.1024 & 47 & 0.0835 & 76 & 0.0378 \\
\hline 6 & 47 & 0.0835 & 71 & 0.0457 & 88 & 0.0189 \\
\hline 8 & 65 & 0.0551 & 94 & 0.0094 & 82 & 0.0283 \\
\hline 10 & 47 & 0.0835 & 64 & 0.0567 & 75 & 0.0394 \\
\hline
\end{tabular}

TABLE 3: Synergism parameter $\left(S_{I}\right)$.

\begin{tabular}{lccccccc}
\hline $\mathrm{HE}(\mathrm{mL})$ & $\theta_{1}$ & $\mathrm{Zn}^{2+} 25(\mathrm{ppm})\left(\theta_{2}\right)$ & $\mathrm{HE}^{2} \mathrm{Zn}^{2+} \theta_{1+2}^{\prime}$ & $S_{I}$ & $\mathrm{Zn}^{2+} 50(\mathrm{ppm})\left(\theta_{2}\right)$ & $\mathrm{HE}^{2} \mathrm{Zn}^{2+} \theta_{1+2}^{\prime}$ & $S_{I}$ \\
\hline 2 & 0.28 & 0.16 & 0.41 & 1.0250 & 0.47 & 0.64 & 1.06 \\
4 & 0.35 & 0.16 & 0.47 & 1.0301 & 0.47 & 0.76 \\
6 & 0.47 & 0.16 & 0.71 & 1.5351 & 0.47 & 0.88 \\
8 & 0.65 & 0.16 & 0.94 & 4.9 & 0.47 & 0.82 \\
10 & 0.47 & 0.16 & 0.64 & 1.2366 & 0.47 & 1.0305 \\
\hline
\end{tabular}

of $8 \mathrm{~mL}$ of $\mathrm{HE}$ solution and $25 \mathrm{ppm}$ of $\mathrm{Zn}^{2+}$ shifts the corrosion potential to $-808 \mathrm{mV}$ versus SCE. The corrosion potential shift is very small. This suggests that the $\mathrm{HE}-\mathrm{Zn}^{2+}$ formulation functions as a mixed inhibitor controlling the anodic reaction and cathodic reaction, to the same extent. The corrosion current value and LPR value for sea water are $6.354 \times 10^{-6} \mathrm{~A} / \mathrm{cm}^{2}$ and $6.500 \times 10^{3} \mathrm{ohm} \mathrm{cm}^{2}$. For the formulation of $\mathrm{HE}(8 \mathrm{~mL})$ and $\mathrm{Zn}^{2+}(25 \mathrm{ppm})$, the corrosion current value is decreased to $5.234 \times 10^{-6} \mathrm{~A} / \mathrm{cm}^{2}$, and the LPR value is increased to $7.752 \times 10^{3} \mathrm{ohm} \mathrm{cm}^{2}$. This indicates that a protective film is formed on the metal surface. When a protective film is formed on the metal surface, LPR value increases and corrosion current value decreases [28].

3.3. Analysis of AC Impedance Spectra. AC impedance spectra have been studied to detect the formation of film on the metal surface. If a protective film is formed, the charge transfer resistance increases and double-layer capacitance value decreases $[29,30]$. The AC impedance spectra of carbon steel immersed in various solutions are shown in Figure 2. The AC impedance parameters, namely, charge transfer resistance $\left(R_{t}\right)$ and double-layer capacitance $\left(C_{\mathrm{dl}}\right)$, (derived from Nyquist plot) are given in Table 6.

The AC impedance parameters, namely, charge transfer resistance $\left(R_{t}\right)$ and double-layer capacitance $\left(C_{\mathrm{dl}}\right)$, are given in Table 6. When carbon steel is immersed in sea water, $R_{t}$ value is $101.10 \mathrm{ohm} \mathrm{cm}^{2}$ and $C_{\mathrm{dl}}$ value is $5.0445 \times$ $10^{-8} \mathrm{~F} / \mathrm{cm}^{2}$. When $\mathrm{HE}$ and $\mathrm{Zn}^{2+}$ are added to sea water, $R_{t}$ value increases from $101.10 \mathrm{ohm} \mathrm{cm}^{2}$ to $123.68 \mathrm{ohm} \mathrm{cm}$ and the $C_{\mathrm{dl}}$ decreases from $5.0445 \times 10^{-8} \mathrm{~F} / \mathrm{cm}^{2}$ to $4.1195 \times$ $10^{-8} \mathrm{~F} / \mathrm{cm}^{2}$. This suggests that a protective film is formed on the surface of the metal. This is further supported by the increase in impedance value $[\log (\mathrm{z} / \mathrm{ohm})]$ from 2.060 to 2.132 (Figure 3). This accounts for the very high IE of HE$\mathrm{Zn}^{2+}$ system.

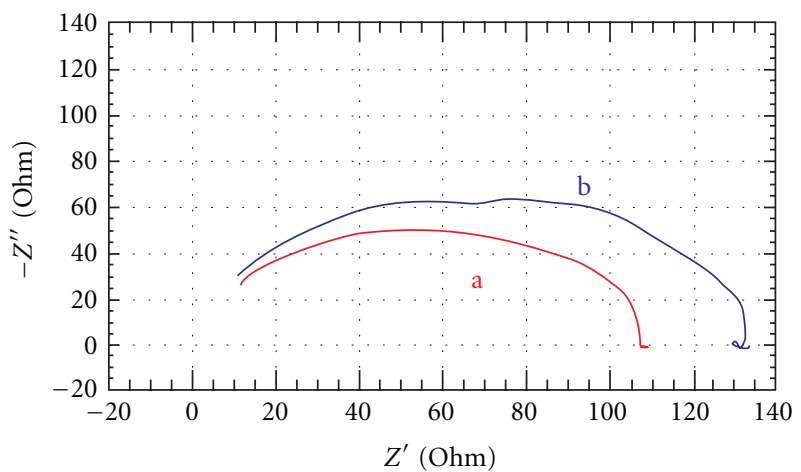

Figure 2: AC impedance spectra of carbon steel immersed in various test solutions (Nyquist plots). (a) Sea water and (b) sea water + HE $8 \mathrm{~mL}+\mathrm{Zn}^{2+} 25 \mathrm{ppm}$.

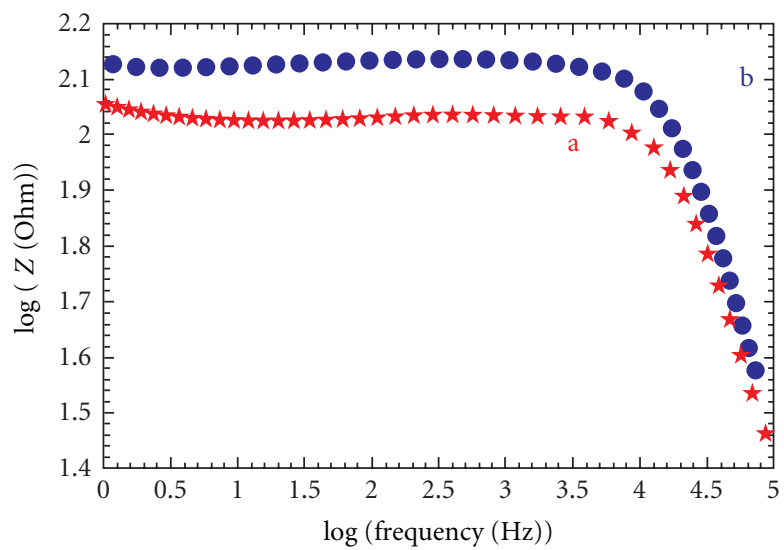

Figure 3: AC impedance spectra of carbon steel immersed in various test solutions (impedance-Bode plots). (a) Sea water and (b) sea water $+\mathrm{HE} 8 \mathrm{~mL}+\mathrm{Zn}^{2+} 25 \mathrm{ppm}$. 
TABle 4: Analysis of variance ( $F$-Test ).

\begin{tabular}{lcccccc}
\hline $\mathrm{Zn}^{2+}(\mathrm{ppm})$ & Source of variance & Sum of squares & Degrees of freedom & Mean square & $F$ & Level of significance of $F$ \\
\hline \multirow{2}{*}{25} & Between & 180 & 1 & 180 & 320 & 0.56 \\
& Within & 2560 & 532 & 1 & 532 & $3<0.05$ \\
\multirow{2}{*}{50} & Between & 1115 & 8 & 139 & \multirow{2}{*}{$P<0.05$} \\
& Within & & 8 & \\
\hline
\end{tabular}

TABle 5: Potentiodynamic polarization curves of carbon steel immersed in various test solution.

\begin{tabular}{|c|c|c|c|c|c|}
\hline System & $E_{\text {corr }} \mathrm{mV}$ versus SCE & $b_{c} \mathrm{mV} /$ decade & $b_{a} \mathrm{mV} /$ decade & LPR ohm $\mathrm{cm}^{2}$ & $I_{\text {corr }} \mathrm{A} / \mathrm{cm}^{2}$ \\
\hline Sea water & -816 & 157 & 239 & $6.500 \times 10^{3}$ & $6.354 \times 10^{-6}$ \\
\hline Sea water $+(8 \mathrm{~mL}) \mathrm{HE}+(25 \mathrm{ppm}) \mathrm{Zn}^{2+}$ & -808 & 156 & 231 & $7.752 \times 10^{3}$ & $5.234 \times 10^{-6}$ \\
\hline
\end{tabular}

TABle 6: AC impedance parameters of carbon steel immersed in various test solutions.

\begin{tabular}{lrcc}
\hline System & $R_{t}$ ohm cm & $C_{\mathrm{dl}} \mathrm{F} / \mathrm{cm}^{2}$ & $\begin{array}{c}\text { Impedance value } \\
\log (\mathrm{z} / \mathrm{ohm})\end{array}$ \\
\hline Sea water & 101.10 & $5.0445 \times 10^{-8}$ & 2.060 \\
$\mathrm{HE}(8 \mathrm{~mL})+$ & 123.68 & $4.1195 \times 10^{-8}$ & 2.132 \\
$\mathrm{Zn}^{2+} 25 \mathrm{ppm}$ & & \\
\hline
\end{tabular}

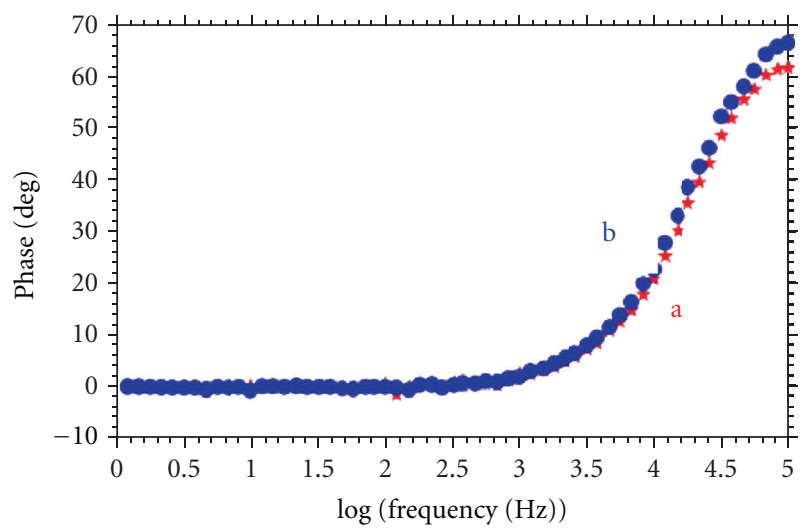

FIGURE 4: AC impedance spectra of carbon steel immersed in various test solutions. (Phase-Bode plots). (a) Sea water, (b) sea water + HE $8 \mathrm{~mL}+\mathrm{Zn}^{2+} 25 \mathrm{ppm}$.

In electrochemical studies, instantaneous corrosion rate is measured. But in weight-loss method, corrosion rate is measured after a longer period in the present study after one day. After a longer period, the protective film becomes more compact and stable. This accounts for the discrepancy in IE, obtained from AC impedance spectra and from weight-loss method (Figure 4).

3.4. Analysis of FTIR Spectra. The active principle in an aqueous extract of henna extract is Lawsone. The red-orange colour of the extract is due to Lawsone (see Scheme 1).

A few drops of an aqueous extract of henna were dried on a glass plate. A solid mass was obtained. Its FTIR spectrum of pure HE is shown in Figure 5(a). The phenolic

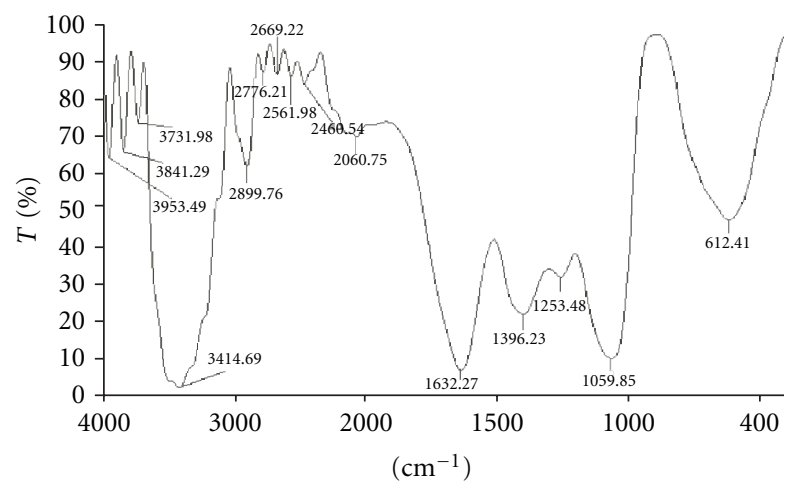

(a)

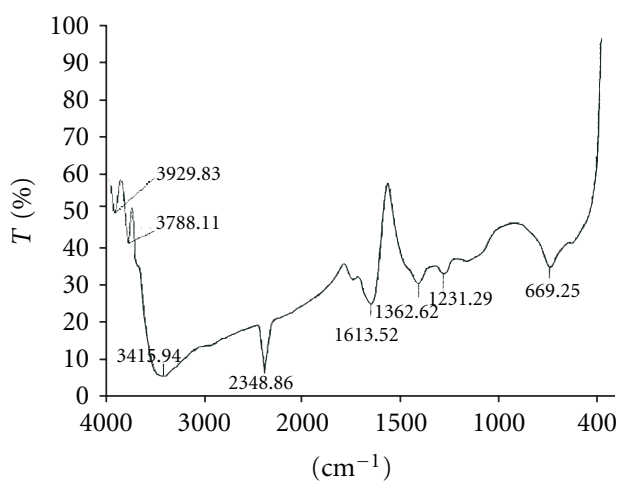

(b)

FIGURE 5: (a) FTIR spectrum of pure henna extract evaporated to dryness and (b) FTIR spectrum of film formed on metal surface after immersion in sea water containing $8 \mathrm{~mL}$ of HE-25 ppm $\mathrm{Zn}^{2+}$.<smiles>O=C1C=C(O)C(=O)c2ccccc21</smiles>

Structure of Lawsone (extract of henna) 2-hydroxy-1,4-naphthoquinone

SCHeme 1 


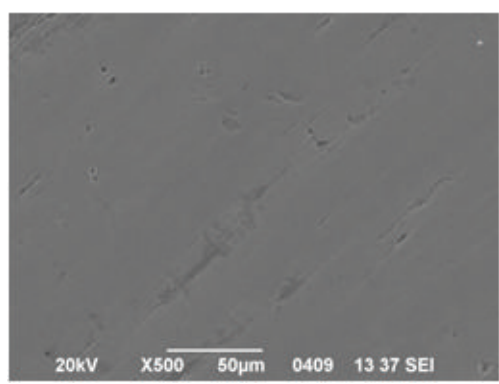

(a)

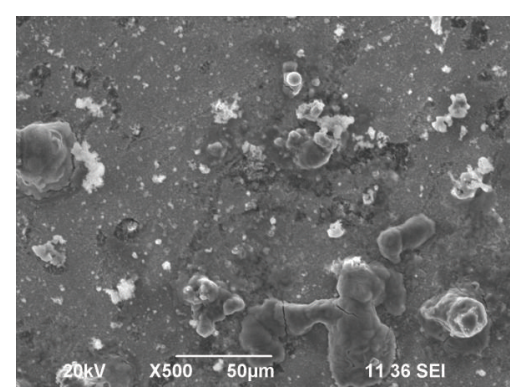

(b)

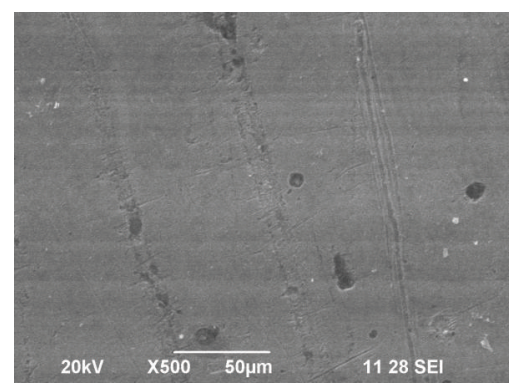

(c)

FIGURE 6: SEM micrographs of; (a) polished carbon steel (control)—Magnification $\times 500$, (b) carbon steel immersed in sea watermagnification $\times 500$, (c) carbon steel immersed in sea water containing $8 \mathrm{ml}$ of $\mathrm{HE}$ and $25 \mathrm{ppm}$ of $\mathrm{Zn}^{2+}$-magnification $-\times 500$.

$\mathrm{O}-\mathrm{H}$ stretch appeared at $3414 \mathrm{~cm}^{-1}$. The $\mathrm{C}=\mathrm{O}$ stretching frequency appeared at $1632 \mathrm{~cm}^{-1}$. Thus Lawsone was characterized by IR spectroscopy [31]

The FTIR spectrum of the protective film formed on the metal after immersion in the sea water for one day containing $8 \mathrm{~mL}$ of $\mathrm{HE}$ and $25 \mathrm{ppm}$ of $\mathrm{Zn}^{2+}$ is shown in Figure 5(b). It is found that the phenolic $\mathrm{O}-\mathrm{H}$ stretch has shifted from $3414 \mathrm{~cm}^{-1}$ to $3415 \mathrm{~cm}^{-1}$. The $\mathrm{C}=\mathrm{O}$ stretching frequency has shifted from $1632 \mathrm{~cm}^{-1}$ to $1613 \mathrm{~cm}^{-1}$. It was inferred that Lawsone has coordinate with $\mathrm{Fe}^{2+}$ through the phenolic oxygen, aromatic ring, and $\mathrm{C}=\mathrm{O}$ group of the $\mathrm{p}$ benzo quinone resulting in the formation of $\mathrm{Fe}^{2+}$-Lawsone complex on the anodic sites of the metal surface. The band at $1362 \mathrm{~cm}^{-1}$ due to the $\mathrm{Zn}(\mathrm{OH})_{2}$ formed on the cathodic sites of the metal surface. Thus FTIR spectral study leads to the conclusion that the protective film consists of $\mathrm{Fe}^{2+}$-Lawsone complex and $\mathrm{Zn}(\mathrm{OH})_{2}$ [32-35].

3.5. SEM Analysis of Metal Surface. The SEM images of magnification $(\times 500)$ of carbon steel specimens immersed in sea water for one day in the absence and presence of inhibitor system are shown in Figure 6 image (b) and image (c), respectively.

The SEM micrographs of polished carbon steel surface (control) in Figure 6 image (a) show the smooth surface of the metal. This shows the absence of any corrosion products formed on the metal surface. The SEM micrographs of carbon steel surface immersed in sea water in Figure 6 image (b) show the roughness of the metal surface which indicates the corrosion of carbon steel in sea water. Figure 6 image (c) indicates that in presence of $8 \mathrm{~mL}$ of $\mathrm{HE}-\mathrm{Zn}^{2+}(25 \mathrm{ppm})$ mixture in sea water, the surface coverage increases which in turn results in the formation of insoluble complex on the surface of the metal (HE- $\mathrm{Zn}^{2+}$ inhibitor complex), and the surface is covered by a thin layer of inhibitors which control the dissolution of carbon steel. Such results have been earlier [36].

3.6. Atomic Force Microscopy Characterization. AFM is a powerful technique to investigate the surface morphology at nano- to microscale and has become a new choice to study the influence of inhibitor on the generation and the progress of the corrosion at the metal/solution interface [3638]. The three-dimensional (3D) AFM morphologies and the AFM cross-sectional profile for polished carbon steel surface (reference sample), carbon steel surface immersed in sea water (blank sample), and carbon steel surface immersed in sea water containing the formulation of $8 \mathrm{~mL}$ of $\mathrm{HE}$ and $25 \mathrm{ppm}$ of $\mathrm{Zn}^{2+}$ are shown in Figure 7 images (a, d, g), (b, e, h), (c, f, i), respectively.

\subsubsection{Root Mean Square Roughness, Average and Roughness} and Peak-to-Valley Value. AFM image analysis is performed to obtain the average roughness, $R_{a}$ (the average deviation of all points roughness profile from a mean line over the evaluation length), root-mean-square roughness, $R_{q}$ (the average of the measured height deviations taken within the evolution length and measured from the mean line), and the maximum peak-to-valley $(p-v)$ height values (largest single peak-to-valley height in five adjoining sampling heights) [36]. Table 7 is a summary of $\left(R_{q}\right),\left(R_{a}\right),(P-V)$ value for carbon steel surface immersed in different environment.

Figure 7 ( $a, d, g$ ) displays the surface topography of uncorroded metal surface. The values of $R_{q}, R_{a}$, and $p$ $v$ height for the polished carbon steel surface (reference sample) are $4.3 \mathrm{~nm}, 3.4 \mathrm{~nm}$, and $35.28 \mathrm{~nm}$, respectively. The slight roughness observed on the polished carbon steel surface is due to atmospheric corrosion.

Figure 7 (b, e, h) displays the corroded metal surface with few pits in the absence of the inhibitor immersed in sea water. The $\left(R_{q}\right),\left(R_{a}\right),(p-v)$ height values for the carbon steel surface are $17.10 \mathrm{~nm}, 13.58 \mathrm{~nm}$, and $92.28 \mathrm{~nm}$, respectively.

These data suggest that carbon steel surface immersed in sea water has a greater surface roughness than the polished metal surface, which shows that the unprotected carbon steel surface is rougher and is due to the corrosion of the carbon steel in sea water environment.

Figure 7 (c, f, i) displays the surface after immersion in sea water containing $8 \mathrm{~mL}$ of $\mathrm{Zn}^{2+}$. The $\left(R_{q}\right),\left(R_{a}\right)(p-$ $v$ ) height values for the carbon steel surface are $11.84 \mathrm{~nm}$, $7.65 \mathrm{~nm}$, and $27.47 \mathrm{~nm}$, respectively. The $\left(R_{q}\right),\left(R_{a}\right)(p$ $v$ ) height values are considerably less in the inhibited environment compared to the uninhibited environment. These parameters confirm that the surface is smoother. The smoothness of the surface is due to the formation of a 


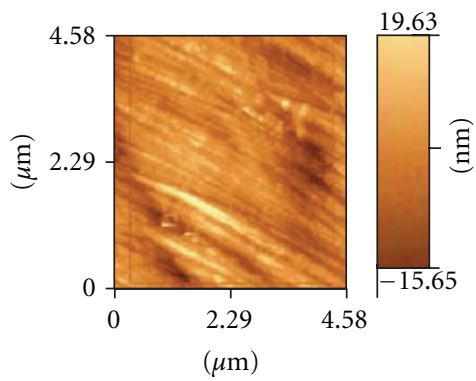

(a)

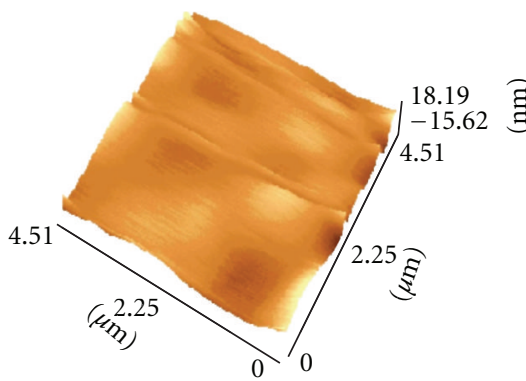

(d)
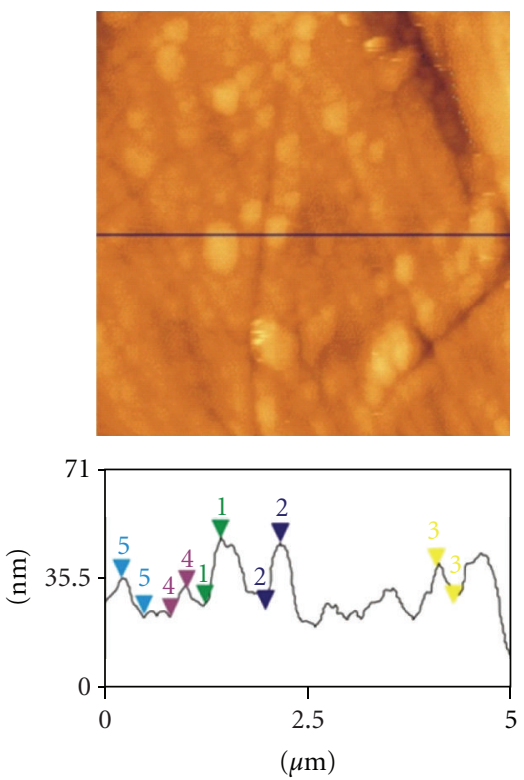

(g)

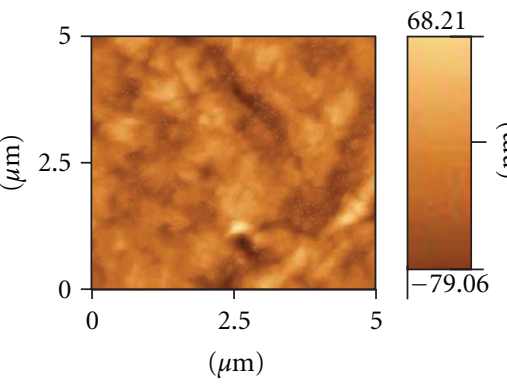

(b)

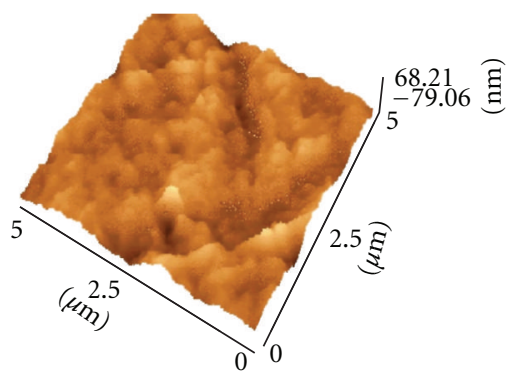

(e)
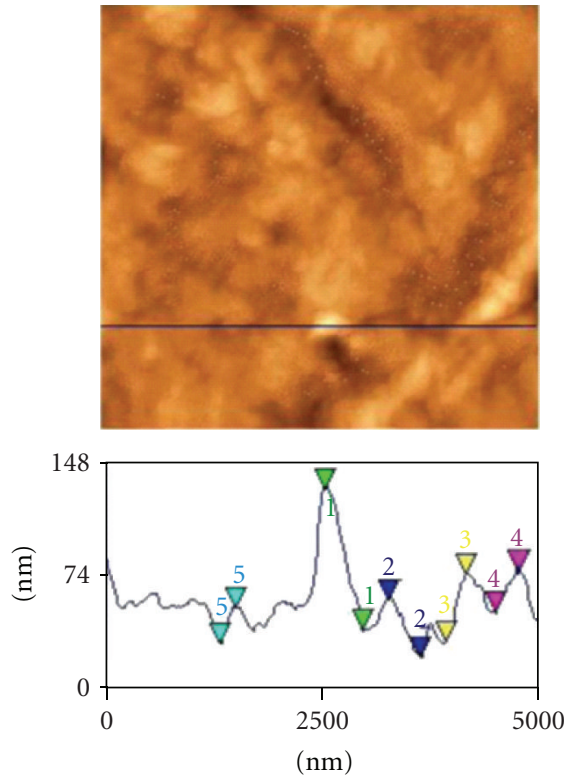

(h)

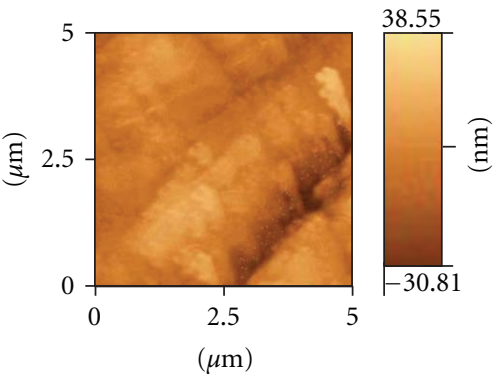

(c)

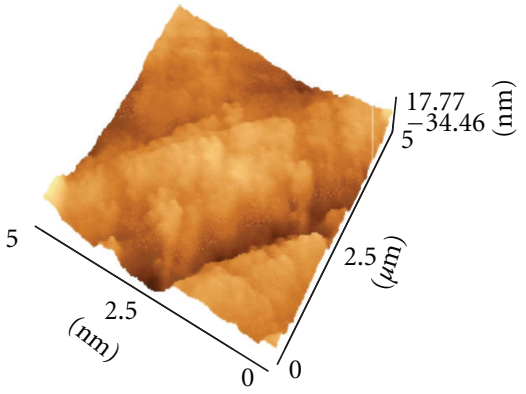

(f)
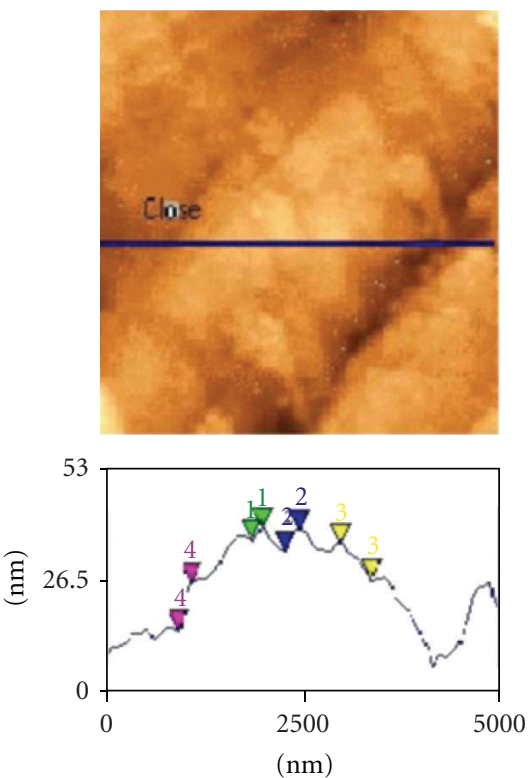

(i)

Figure 7: Two-dimensional AFM images of the surface of (a) polished carbon steel (control); (b) carbon steel immersed in sea water (blank); (c) carbon steel immersed in sea water containing $\mathrm{HE}(8 \mathrm{~mL})+\mathrm{Zn}^{2+}(25 \mathrm{ppm})$. Three-dimensional AFM images of the surface of $(\mathrm{d})$ polished carbon steel (control); (e) carbon steel immersed in sea water (blank); (f) carbon steel immersed in sea water containing $\mathrm{HE}(8 \mathrm{~mL})+\mathrm{Zn}{ }^{2+}$ $(25 \mathrm{ppm})$. AFM cross-sectional images of the surface of $(\mathrm{g})$ polished carbon steel (control); (h) carbon steel immersed in sea water (blank); (i) carbon steel immersed in sea water containing $\mathrm{HE}(8 \mathrm{~mL})+\mathrm{Zn}^{2+}(25 \mathrm{ppm})$.

TABLE 7: AFM data for carbon steel surface immersed in inhibited and uninhibited environment.

\begin{tabular}{|c|c|c|c|}
\hline Samples & $\begin{array}{l}\text { RMS }\left(R_{q}\right) \text { roughness } \\
(\mathrm{nm})\end{array}$ & $\begin{array}{l}\text { Average }\left(R_{a}\right) \text { roughness } \\
(\mathrm{nm})\end{array}$ & $\begin{array}{l}\text { Maximum peak-to-valley } \\
\text { height (nm) }\end{array}$ \\
\hline (1) Polished carbon steel (Control) & 4.33 & 3.41 & 35.28 \\
\hline (2) Carbon steel immersed in sea water (blank) & 17.10 & 13.58 & 92.28 \\
\hline $\begin{array}{l}\text { (3) Carbon steel immersed in sea water }+\mathrm{HE}(8 \mathrm{~mL}) \\
+\mathrm{Zn}^{2+} 25(\mathrm{ppm})\end{array}$ & 11.8 & 7.65 & 27.47 \\
\hline
\end{tabular}


compact protective film of $\mathrm{Fe}^{2+}-\mathrm{HE}$ complex and $\mathrm{Zn}(\mathrm{oH})_{2}$ on the metal surface thereby inhibiting the corrosion of carbon steel [36].

3.7. Mechanism of Corrosion Inhibition. Weight-loss method reveals that the formulation consisting of $8 \mathrm{~mL}$ of $\mathrm{HE}$ and $25 \mathrm{ppm}$ of $\mathrm{Zn}^{2+}$ offers $94 \%$ IE to carbon steel immersed in sea water. A synergistic effect exists between $\mathrm{HE}$ and $\mathrm{Zn}^{2+}$. Polarization study reveals that $\mathrm{HE}-\mathrm{Zn}^{2+}$ system functions as a mixed inhibitor. AC impedance spectra reveal that a protective film is formed on the metal surface. FTIR spectra reveal that the protective film consists of $\mathrm{Fe}^{2+}$-Lawsone complex and $\mathrm{Zn}(\mathrm{OH})_{2}$.

In order to explain the Previous facts in a holistic way, the following mechanism of corrosion inhibition is proposed. When the formulation consisting of sea water, henna extract, and $\mathrm{Zn}^{2+}$ is prepared, there is formation of $\mathrm{Zn}^{2+}$-Lawsone complex in solution.

(i) When carbon steel is immersed in the solution, the $\mathrm{Zn}^{2+}$-Lawsone complex diffuses from the bulk of the solution towards the metal surface.

(ii) On the metal surface, $\mathrm{Zn}^{2+}$-Lawsone complex is converted into $\mathrm{Fe}^{2+}$-Lawsone complex. $\mathrm{Zn}^{2+}$ is released $\mathrm{Zn}^{2+}$

$$
\text { lawsone }+\mathrm{Fe}^{2+} \longrightarrow \mathrm{Fe}^{2+} \text {-Lowsone }+\mathrm{Zn}^{2+} \text {. }
$$

(iii) The released $\mathrm{Zn}^{2+}$ combines with $\mathrm{OH}^{-}$to form $\mathrm{Zn}(\mathrm{OH})_{2}$ on the cathodic sites:

$$
\mathrm{Zn}^{2+}+2 \mathrm{OH}^{-} \longrightarrow \mathrm{Zn}(\mathrm{OH})_{2} \downarrow
$$

(iv) Thus the protective film consists of $\mathrm{Fe}^{2+}$-Lawsone complex and $\mathrm{Zn}(\mathrm{OH})_{2}$. This accounts for the synergistic effect.

\section{Conclusions}

The present study leads to the following conclusions.

(1) The formulation consisting of $8 \mathrm{~mL} \mathrm{HE}$ and $25 \mathrm{ppm}$ $\mathrm{Zn}^{2+}$ has $94 \%$ inhibition efficiency to carbon steel immersed in sea water.

(2) Polarization study reveals that $\mathrm{HE}-\mathrm{Zn}^{2+}$ system functions as a mixed inhibitor.

(3) AC impedance spectra reveal that a protective film is formed on the metal surface.

(4) FTIR spectra reveal that the protective film consists of $\mathrm{Fe}^{2+}$-Lawsone complex and $\mathrm{Zn}(\mathrm{OH})_{2}$.

\section{Acknowledgment}

The authors are thankful to their respective management and Defence Research and Development Organisation, New Delhi.

\section{References}

[1] F. L. LaQue, Marine Corrosion and Prevention, John Wiley \& Sons, New York, NY, USA, 1975.

[2] D. B. Anderson and R. W. Ross Jr., "Proection of steel pilling in marine splash and spray zone-Metallic sheathing concept," pp. 461-473, Proceeding of the 4th International Congress on Marine Corrosion and Fouling, Juan-les-Pins, France, 1976.

[3] C. P. Larrabee, "Corrosion resistance of high strength low alloy steel as influenced by composition and environment," Corrosion, vol. 9, pp. 259-371, 1953.

[4] A. A. Humbles, "The cathodic protection of steel in seawater," Corrosion, September 1949.

[5] O. K. Abola and A. O. James, "The effects of Aloe vera extract on corrosion and kinetics of corrosion process of zinc in $\mathrm{HCl}$ solution," Corrosion Science, vol. 52, no. 2, pp. 661-664, 2010.

[6] E. E. Ebenso, T. Arslan, F. Kandemirli, N. Caner, and I. Love, "Quantum chemical studies of some rhodanine azosulpha drugs as corrosion inhibitors for mild steel in acidic medium," International Journal of Quantum Chemistry, vol. 110, no. 5, pp. 1003-1018, 2010.

[7] N. O. Eddy, U. J. Ibok, E. E. Ebenso, A. Nemr, and E. S. H. El Ashry, "Quantum chemical study of the inhibition of the corrosion of mild steel in $\mathrm{H}_{2} \mathrm{SO}_{4}$ by some antibiotics," Journal of Molecular Modeling, vol. 15, no. 9, pp. 1085-1092, 2009.

[8] A. I. Onen, B. T. Nwufo, E. E. Ebenso, and R. M. Hlophe, "Titanium (IV) oxide as corrosion inhibitor for aluminium and mild steel in acidic medium," International Journal of Electrochemical Science, vol. 5, pp. 1563-1573, 2010.

[9] E. E. Oguzie, "Corrosion inhibition of aluminium in acidic and alkaline media by Sansevieria trifasciata extract," Corrosion Science, vol. 49, no. 3, pp. 1527-1539, 2007.

[10] A. Sharmila, A. A. Prema, and P. A. Sahayaraj, "Influence of Murraya koenigii (curry leaves) extract on the corrosion inhibition of carbon steel in HCL solution," Rasayan Journal of Chemistry, vol. 3, no. 1, pp. 74-81, 2010.

[11] A. Y. El-Etre, "Inhibition of aluminum corrosion using Opuntia extract," Corrosion Science, vol. 45, no. 11, pp. 2485-2495, 2003.

[12] E. E. Ebenso, U. J. Ibok, U. J. Ekpe et al., "Corrosion inhibition studies of some plant extracts on aluminium in acidic medium," Transactions of the SAEST, vol. 39, no. 4, pp. 117123, 2004.

[13] A. D. Odiongenyi, S. A. Odoemelam, and N. O. Eddy, "Corrosion inhibition and adsorption properties of ethanol extract of Vernonia amygdalina for the corrosion of mild steel in $\mathrm{H}_{2} \mathrm{SO}_{4}$," Portugaliae Electrochimica Acta, vol. 27, no. 1, pp. 33-45, 2009.

[14] E. E. Oguzie, "Inhibition of acid corrosion of mild steel by Telfaria occidentalis extract," Pigment and Resin Technology, vol. 34, no. 6, pp. 321-326, 2005.

[15] P. C. Okafor, M. E. Ikpi, I. E. Uwah, E. E. Ebenso, U. J. Ekpe, and S. A. Umoren, "Inhibitory action of Phyllanthus amarus extracts on the corrosion of mild steel in acidic media," Corrosion Science, vol. 50, no. 8, pp. 2310-2317, 2008.

[16] E. A. Noor, "Temperature effects on the corrosion inhibition of mild steel in acidic solutions by aqueous extract of fenugreek leaves," International Journal of Electrochemical Science, vol. 2, pp. 996-1017, 2007.

[17] A. Y. El-Etre, "Inhibition of acid corrosion of carbon steel using aqueous extract of olive leaves," Journal of Colloid and Interface Science, vol. 314, no. 2, pp. 578-583, 2007.

[18] U. Anozie, C. S. Akoma, and L. A. Nnanna, "Corrosion inhibition of aluminium alloy in acidic medium by Euphorbia hirta 
and Dialum guineense extracts," International Journal of Pure and Applied Sciences and Technology, vol. 6, no. 2, pp. 79-88, 2011.

[19] I. B. Obot and N. O. Obi-Egbedi, "Ginseng root: a new efficient and effective eco-friendly corrosion inhibitor for aluminium alloy of type AA 1060 in hydrochloric acid solution," International Journal of Electrochemical Science, vol. 4, no. 9, pp. 1277-1288, 2009.

[20] S. J. Arockia, S. Rajendran, S. V. Ganga, A. J. Amalraj, and B. Naranyansamy, "Corrosion inhibition by beet root extract," Portugaliae Electrochemica Acta, vol. 27, no. 1, pp. 1-11, 2009.

[21] P. B. Raja, A. A. Rahim, H. Osman, and K. Awang, "Inhibitory effect of Kopsia singapurensis extract on the corrosion behavior of mild steel in acid media," Acta Physico-Chimica Sinica, vol. 26, no. 8, pp. 2171-2176, 2010.

[22] K. S. Beenakumari, "Inhibitory effects of Murraya koenigii (Curry leaf) leaf extracts on the corrosion of mild steel in $1 \mathrm{M}$ Hcl," Green Chemistry Letters and Reviews, vol. 4, no. 2, pp. 117-120, 2011.

[23] T. Umamathi, J. A. Selvi, S. A. Kanimozhi, S. Rajendran, and A. J. Amalraj, "Effect of $\mathrm{Na}_{3} \mathrm{PO}_{4}$ on the corrosion inhibition efficiency of EDTA- $\mathrm{Zn}^{2+}$ system for carbon steel in aqueous solution," Indian Journal of Chemical Technology, vol. 15, no. 6, pp. 560-565, 2008.

[24] S. Rajendran, S. Shanmugapriya, T. Rajalakshmi, and A. J. A. Raj, "Corrosion inhibition by an aqueous extract of rhizome powder," Corrosion, vol. 61, no. 7, pp. 685-692, 2005.

[25] K. Anuradha, R. Vimala, B. Narayanaswamy, J. A. Selvi, and S. Raji, "Corrosion inhibition of carbon steel in low chloride media by an aqueous extract of Hibiscus rosa-sinensis linn," Chemical Engineering Communications, vol. 195, no. 3, pp. 352-366, 2008.

[26] S. Rajendran, A. Raji, J. A. Selvi, A. Rosaly, and S. Thangasamy, "Evaluation of gender bias in use of modular instruction and concepts of organic chemistry Nomenclature," Journals of Material Education, vol. 29, pp. 245-258, 2007.

[27] S. Rajendran, A. Raji, J. A. Selvi, A. Rosaly, and S. Thangasamy, "Parents' education and achievement scores in chemistry," Edutracks, vol. 6, pp. 30-33, 2007.

[28] F. R. Selvarani, S. Santhamadharasi, J. W. Sahayaraj, A. J. Amalraj, and S. Rajendran, "Synergistic effect of succinic acid and $\mathrm{Zn}^{2+}$ in controlling corrosion of carbon steel," Bulletin of Electrochemistry, vol. 20, no. 12, pp. 561-566, 2004.

[29] J. Sathiabama, S. Rajendran, and J. A. Selvi, "Erilchrome Black-T as corrosion inhibition for carbon steel in well water," Bulletin of Electrochemistry, vol. 22, pp. 363-370, 2006.

[30] S. Rajendran, M. Manivannan, J. W. Sahayaraj et al., "Corrosion behavior of aluminium in methyl orange solution at $\mathrm{pH}$ 11," Transactions of the SAEST, vol. 41, no. 2, pp. 63-67, 2006.

[31] R. M. Silverstein, G. C. Bassler, and T. C. Morrill, Spectrometric, Identification of Organic Compounds, John Wiley \& Sons, New York, NY, USA, 1986.

[32] I. Sekine and Y. Hirakawa, "Effect of 1-hydroxyethylidene-1, 1 -diphosphonic acid on the corrosion of SS 41 steel in $0.3 \%$ sodium chloride solution," Corrosion, vol. 42, no. 5, pp. 272277, 1986.

[33] S. Rajendran, S. P. Sridevi, N. Anthony, A. J. Amalraj, and M. Sundaravadivelu, "Corrosion behaviour of carbon steel in polyvinyl alcohol," Anti-Corrosion Methods and Materials, vol. 52, no. 2, pp. 102-107, 2005.

[34] S. Rajendran, M. Agasta, R. Bama Devi, B. Shyamala Devi, K. Rajam, and J. Jayasundari, "Corrosion inhibition of aqueous extract of Henna leaves," Zastita Materijala, vol. 50, no. 2, pp. 77-84, 2009.
[35] R. M. Silverstein and F. X. Webster, Spectrometric Identification of Organic Compounds, John Wiley \& Sons, New York, NY, USA, 6th edition, 2007.

[36] B. Sherine, A. J. Abdul Nasser, and S. Rajendran, "Inhibitive action of hydroquinone- $\mathrm{Zn}^{2+}$ system in controlling the corrosion of carbon steel in well water," International Journal of Engineering Science and Technology, vol. 2, no. 4, pp. 341357,2010

[37] A. K. Singh and M. A. Quraishi, "Investigation of the effect of disulfiram on corrosion of mild steel in hydrochloric acid solution," Corrosion Science, vol. 53, no. 4, pp. 1288-1297, 2011.

[38] B. Wang, M. Du, J. Zhang, and C. J. Gao, "Electrochemical and surface analysis studies on corrosion inhibition of Q235 steel by imidazoline derivative against $\mathrm{CO}_{2}$ corrosion," Corrosion Science, vol. 53, no. 1, pp. 353-361, 2011. 

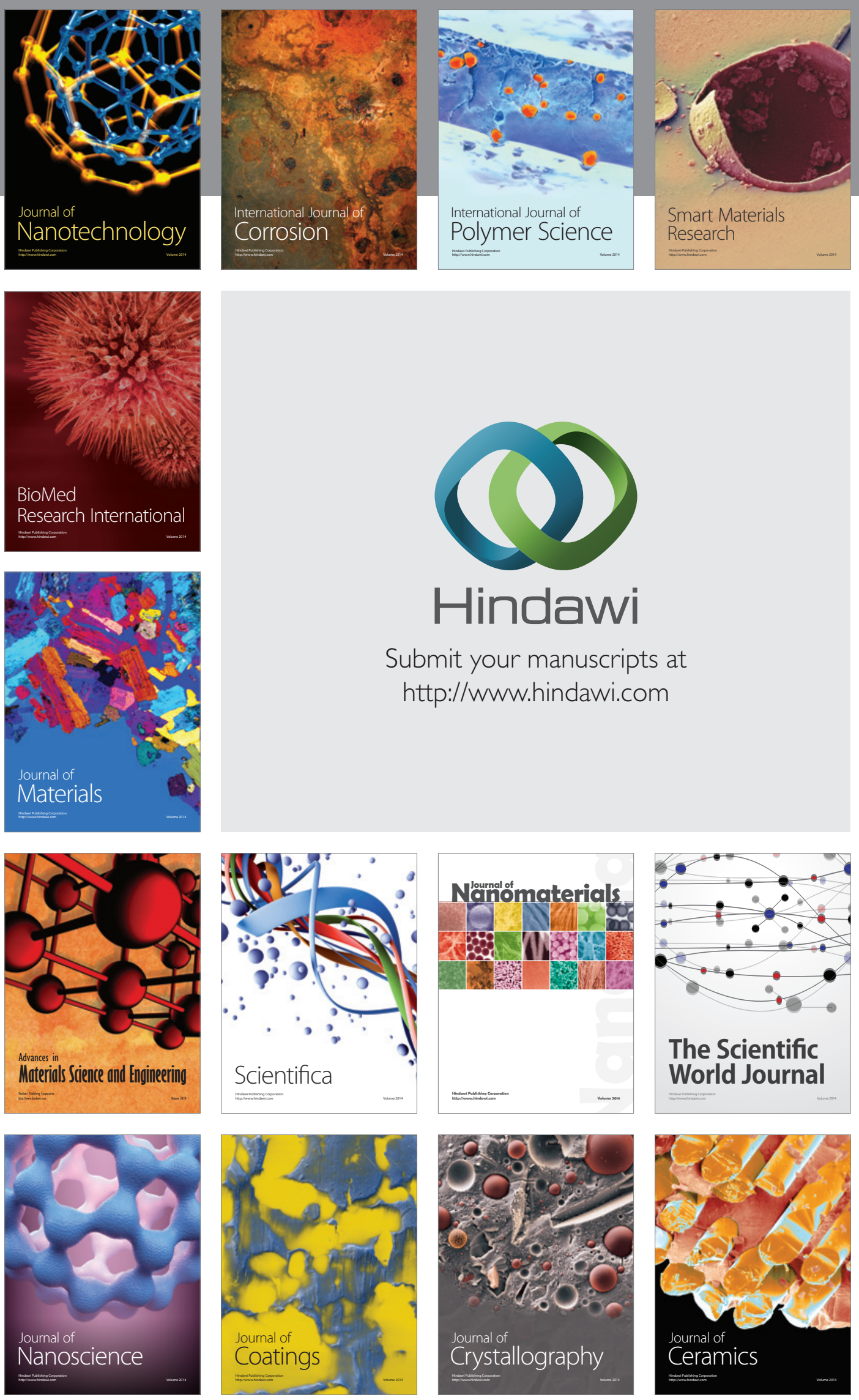

The Scientific World Journal

Submit your manuscripts at

http://www.hindawi.com

\section{World Journal}

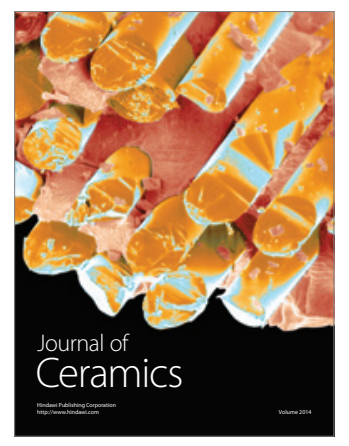

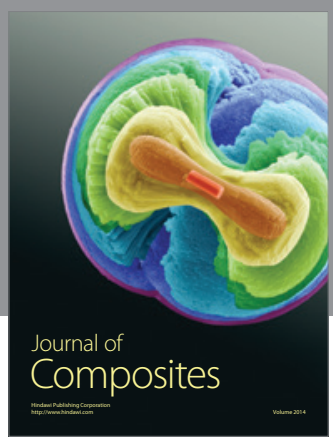
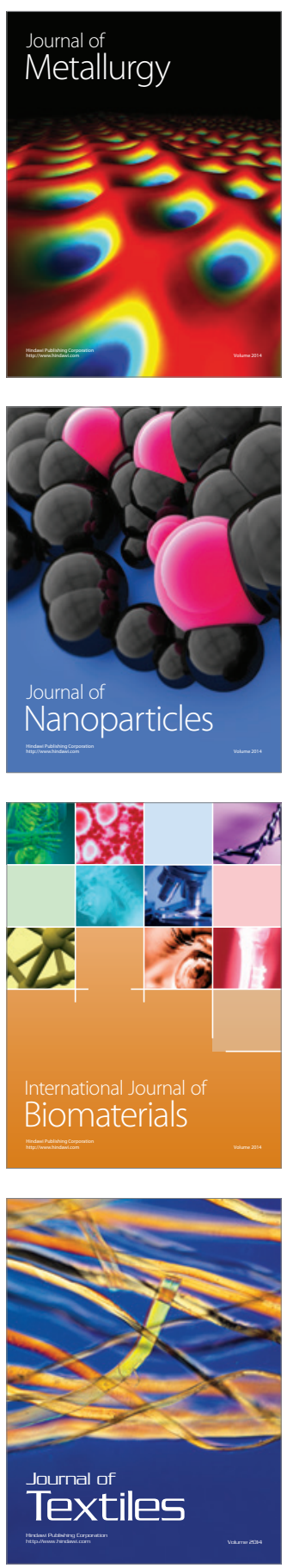